DOI:

\title{
SIMULATION OF SOLVENT SUBLATION PROCESS TO FORECAST THE AMOUNT OF REMOVED DYES
}

\author{
T. Obushenko, O. Sanginova, N. Tolstopalova, K. Reminna \\ National Technical University of Ukraine "Igor Sikorsky Kyiv Polytechnic Institute" \\ Kyiv, Ukraine, e-mail: tio1963@gmail.com
}

Article history:
Received 29 April 2019
Accepted 15 May 2019
Print 25 June 2019

define the process variables that have the real impact on the solvent sublation process. The STAR system mathematical tools were used to find a proper model that govern the change of dye residual concentration over time, as well as to carry out parametric identification. The simulation results show that the models have a good performance in the simulation and prediction of the cationic and anionic dyes removal from aqueous solutions. The results can be used to optimize the solvent sublation process as a technique of wastewater treatment.

Keywords: dye, simulation, solvent sublation, waste water.

\section{Introduction}

A large amount of wastewater contains a variety of toxic and hazardous dyes. Significant part of the wastewater comes from the factories producing these dyes, as well as from the textile industry. An undertreated wastewater entering the water objects as a result of intensive industry activity has led to the fact that in the last 25-30 years the resource of self-healing properties of water resources of Ukraine has almost been depleted (Ratnaweera et al., 2015).

Dyes form a large part of organic compounds that contains unsaturated bonds (chromophores) such as $-\mathrm{C}=\mathrm{C}-,-\mathrm{N}=\mathrm{N}-$ and $-\mathrm{C} \equiv \mathrm{N}-$, as well as functional groups such as $-\mathrm{NH},-\mathrm{OH},-\mathrm{COOH}$ and $-\mathrm{SO}_{3} \mathrm{H}$. Chromophores define coloring ability of dyes while functional groups responsible for dyes fixation on tissues.

The textile industry uses active dyes with high color characteristics that have resistant physicochemical and physical-mechanical parameters. Therefore, getting into the environment, dyes easily color the water and the surrounding area, thereby creating unfavorable aesthetic perception, worsening the organoleptic indicators of water. In addition, dyes can also significantly affect the photosynthesis capability of the water objects inhabitants, reducing the intensity of light penetration and may also be toxic to some aquatic species of flora and fauna due to aromatic rings and chlorine substitutes. This can lead to mass death of fish, violation of self-purification processes, sanitary state of the water objects, severe human poisoning.

According to recent publications (Nesterova and Saribekov, 2010, Forgacs et al., 2004, Leskiv, 2008), hybrid methods application allows to treat waste water more efficiently. One of the advanced wastewater treatment technique that removed dyes is solvent sublation (Lu, 2001, Bi 2007, 2010). This technique combines two methods - ion flotation and solvent extraction - and is based on the ascension of gas bubbles to the surface; thus, the polutant (sublate) is transferred to the organic phase (Lu 2001, 2007). Surfactants are used in the solvent sublation process as collectors. The surfactant molecules directly participate in the formation of the sublate and affect the removal rate. The surfactants reduce the value of free surface energy at the boundary of the organic and water phases, and stabilize the surface of the bubbles. The surfactants are bound to dye ions in insoluble hydrophobic sublattices, which are ascended from the water phase to organic (Lu 2003, Astrelin I. M. et al., 2013). 
Simulation of the solvent sublation processes of dyes removal allows studying the influence of the process variables on the efficiency of the process, to justify the choice of the surfactants and to predict the amount of the removed dye.

The aim of the paper is simulation of the solvent sublation process as a wastewater treatment technique in order to specify the process variables that have a significant impact on the removal of various types of dyes.

\section{Experimental Part}

\section{Equipment and Materials Used}

A cylindrical glass column with a diameter of $35 \mathrm{~mm}$, compressor to supply air at the bottom of the column through a porous glass partition were used to simulate the solvent sublation process. The gas flow was controlled by a rotameter. Scanning spectrophotometer Portlab 501 model was used to define a residual dye concentration. $\mathrm{PH}$ meter $\mathrm{PH}-150 \mathrm{MI}$ model was used to measure $\mathrm{pH}$ of aqueous solutions.

Dyes which are analyzed include water-soluble cationic and anionic dyes: Malachite green, Methyl violet, Crystal violet, Methylene blue, Bromocresol green, Bromophenol blue, Disodium Reactive Blue 4, Indigo carmine and Acid Red 1. A brief description of each type of dyes are presented in Tables 1 and 2. Sodium hydroxide $0.1 \mathrm{~mol} / \mathrm{dm}^{3}$ and Hydrochloric Acid $0.1 \mathrm{~mol} / \mathrm{dm}^{3}$ were used to the $\mathrm{pH}$ correction. Anionic surfactant sodium dodecyl sulfate and cationic surfactant hexadecylpyridinium bromide were used to remove cationic and anionic dyes respectively.

Table 1. Anionic Dyes.

\begin{tabular}{|c|c|c|c|}
\hline$\#$ & Name & Chemical and Skeletal formulas & Brief description \\
\hline 1 & Acid Red 1 & $\mathrm{C}_{18} \mathrm{H}_{13} \mathrm{~N}_{3} \mathrm{Na}_{2} \mathrm{O}_{8} \mathrm{~S}_{2}$ & $\begin{array}{l}\text { Homogeneous powder of red color } \\
\text { is used for dyeing of natural and } \\
\text { artificial silk. Coloring is easily } \\
\text { washed off with hot soapy water. }\end{array}$ \\
\hline 2 & $\begin{array}{l}\text { Disodium } \\
\text { Reactive Blue } \\
4\end{array}$ & $\mathrm{C}_{23} \mathrm{H}_{12} \mathrm{Cl}_{2} \mathrm{~N}_{6} \mathrm{Na}_{2} \mathrm{O}_{8} \mathrm{~S}_{2}$ & $\begin{array}{l}\text { Dichlorotriazin active dye, giving } \\
\text { the material a navy color. Like } \\
\text { other triazine active dyes, it is fixed } \\
\text { as a result of interaction the dye } \\
\text { with the functional groups of the } \\
\text { fiber to form a covalent bond. }\end{array}$ \\
\hline 3 & $\begin{array}{l}\text { Bromophenol } \\
\text { blue }\end{array}$ & $\begin{array}{l}\mathrm{C}_{19} \mathrm{H}_{10} \mathrm{Br}_{4} \mathrm{O}_{5} \mathrm{SNa}_{2} \\
\mathrm{Na}^{+}{ }^{-}{ }^{-}\end{array}$ & $\begin{array}{l}\text { Natural dye, also used in laboratory } \\
\text { practice as a pH-indicator and } \\
\text { marker for electrophoresis. It can } \\
\text { be applied in the } \mathrm{pH} \text { range from } 3.0 \\
\text { to 4.6. At pH below 3.0, the } \\
\text { solution is yellow, above } 4.6 \text { is } \\
\text { purple. }\end{array}$ \\
\hline 4 & $\begin{array}{l}\text { Indigo } \\
\text { carmine }\end{array}$ & $\mathrm{C}_{16} \mathrm{H}_{8} \mathrm{~N}_{2} \mathrm{Na}_{2} \mathrm{O}_{8} \mathrm{~S}_{2}$ & $\begin{array}{l}\text { It is used at ink manufacture, food } \\
\text { coloring (E132, also known as } \\
\text { indigotin), as well as in chemistry }\end{array}$ \\
\hline
\end{tabular}




\begin{tabular}{|l|l|l} 
as redox and acid-base indicator \\
and reagent for the $\mathrm{O}_{2}$ and $\mathrm{O}_{3}$ \\
photometric determination. It is \\
well known in medicine as a \\
diagnostic material, for example, in \\
histological studies.
\end{tabular}

Table 2. Cationic Dyes.

\begin{tabular}{|c|c|c|c|}
\hline \# & Name & Chemical formula & Brief description \\
\hline 1 & $\begin{array}{l}\text { Malachite } \\
\text { green }\end{array}$ & $\mathrm{Cl}_{23} \mathrm{H}_{25} \mathrm{~N}_{2} \mathrm{Cl}$ & $\begin{array}{l}\text { It is an acid-base indicator: in aqueous } \\
\text { solutions in a strongly acidic medium, it } \\
\text { has a yellow color, and at } \mathrm{pH} \text { above } 11.6 \text { it } \\
\text { is discolored due to addition of hydroxyl to } \\
\text { form triphenylcarbinol. It has a wide use, } \\
\text { although it is traditionally used as a dye. It } \\
\text { is also used in microscopy, veterinary, } \\
\text { photometric studies. }\end{array}$ \\
\hline 2 & Methyl violet & $\begin{array}{r}\mathrm{C}_{24} \mathrm{H}_{28} \mathrm{~N}_{3} \mathrm{Cl} \\
\mathrm{H}_{3} \mathrm{C} 、\end{array}$ & $\begin{array}{l}\text { It belongs to the class of aniline dyes. It is } \\
\text { an acid-base indicator, thus it is most often } \\
\text { used in analytical chemistry. In addition, it } \\
\text { is used in microbiology for the coloring of } \\
\text { pathogenic organisms and their detection. } \\
\text { The industry uses it as an ingredient in the } \\
\text { ink and it is used limited to the fabrics and } \\
\text { wool dyeing. }\end{array}$ \\
\hline 3 & Crystal violet & $\begin{array}{r}\mathrm{C}_{25} \mathrm{~N}_{3} \mathrm{H}_{30} \mathrm{Cl} \\
\mathrm{H}_{3}\end{array}$ & $\begin{array}{l}\text { It is also known as the Gencian Violet and } \\
\text { belongs to the class of aniline dyes. It is } \\
\text { most often used in analytical chemistry as } \\
\text { an indicator, in microbiology as a detecor } \\
\text { of pathogenic organisms. In industry it is } \\
\text { used as an ink component the or as a dye } \\
\text { for fabrics. }\end{array}$ \\
\hline 4 & $\begin{array}{l}\text { Methylene } \\
\text { blue }\end{array}$ & $\mathrm{C}_{16} \mathrm{H}_{18} \mathrm{ClN}_{3} \mathrm{~S}$ & $\begin{array}{l}\text { Organic basic thiazine dye used for dyeing } \\
\text { cotton, wool and silk in a bright blue color, } \\
\text { but the paint is destroyed in the light. In } \\
\text { analytical chemistry it is used to determine } \\
\text { chlorates, perchlorates, cations of mercury, } \\
\text { tin, magnesium, calcium, cobalt, cadmium. } \\
\text { In medicine, it is used as an antiseptic and } \\
\text { antidote for poisoning with cyanide, } \\
\text { carbon monoxide and hydrogen sulfide. } \\
\text { Also used in microscopy, aquarium and } \\
\text { photography. }\end{array}$ \\
\hline 5 & $\begin{array}{l}\text { Bromocresol } \\
\text { green }\end{array}$ & $\mathrm{C}_{21} \mathrm{H}_{14} \mathrm{Br}_{4} \mathrm{O}_{5} \mathrm{~S}$ & $\begin{array}{l}\text { It is actively used in analytical chemistry in } \\
\text { acid-base titration. During researches it is } \\
\text { possible to observe the transition of } \\
\text { coloring of solution from light yellow to } \\
\text { blue color at pH interval from } 3.8 \text { to } 5.4 \text {. } \\
\text { Due to its excellent chemical properties, }\end{array}$ \\
\hline
\end{tabular}




such a reagent is often used to precisely
determine albumin in plasma or serum.

\section{Static laboratory tests}

Laboratory tests are carried out for each analyzed dye at $25^{\circ} \mathrm{C}$ and to study the effect of process variables such as $\mathrm{pH}$, the dye:surfactant ratio and the process time. In all tests, the initial dye concentration is $10 \mathrm{mg} / \mathrm{dm}^{3}$, the volume of the studied aqueous solution $-200 \mathrm{~cm}^{3}$, the organic part $10 \mathrm{~cm}^{3}$. The solvent sublation process lasted until the residual dye concentration came to stay at constant level.

Dye removal degree is calculated by equation (1):

$$
R(\%)=\left(\frac{C_{0-} C_{r}}{C_{0}}\right) \times 100
$$

in which, $C_{o}$ and $C_{r}$ are the initial concentration of dye in the solution $\left(\mathrm{mg} / \mathrm{dm}^{3}\right)$ and the residual concentration of dye $\left(\mathrm{mg} / \mathrm{dm}^{3}\right)$ respectively.

\section{Solvent Sublation Process Simulation}

In order to determine the process variables that have a real impact on the solvent sublation process, a correlation analysis is performed. A scatter plot is used to define a matching between process variables and dye residual concentration. Correlation coefficient is calculated for each "process parameter- residual concentration" pair.

Using system the STAR (Sanginova and Kulevskiy, 2018) software, it is proposed to use an ordinary first-order differential equation (2) as a mathematical model that simulate residual concentration behaviour of various dyes:

$$
T \cdot y^{\prime}+y=Q\left(x_{1}, x_{2}, \mathrm{~K}, x_{n}\right)
$$

in which, $y$ is the residual dye concentration $\mathrm{mg} / \mathrm{dm}^{3}, x_{i}(i=(\overline{1, n}))$ are the process variables that have the large impact on the process, $\mathrm{n}$ - number of process variables.

The coefficients of mathematical models for each dye are computed using the GEM subsystem of the STAR system. The GEM subsystem is also used to calculate such statistical parameters as multiple correlation coefficient $r$, Fisher ratio $F$ and root-mean-square deviation (RMSD) $\sigma$.

\section{Results and discussion}

The results of correlation analysis showed that $\mathrm{pH}$, dye:surfactant ratio and process time the most closely related to the dye residual concentration. An example of a scatter plot for Methylene blue is shown in Fig. 1, in which $\mathrm{X}$ is the dye:surfactant ratio and $\mathrm{Y}$ is the residual concentration. The correlation coefficient in this case is -0.889 , thus, the matching between the dye:surfactant ratio and the dye residual concentration is quite strong. Correlation analysis is performed for each type of dye. The summarized results of the correlation analysis are presented in Tables 3 and 4. 


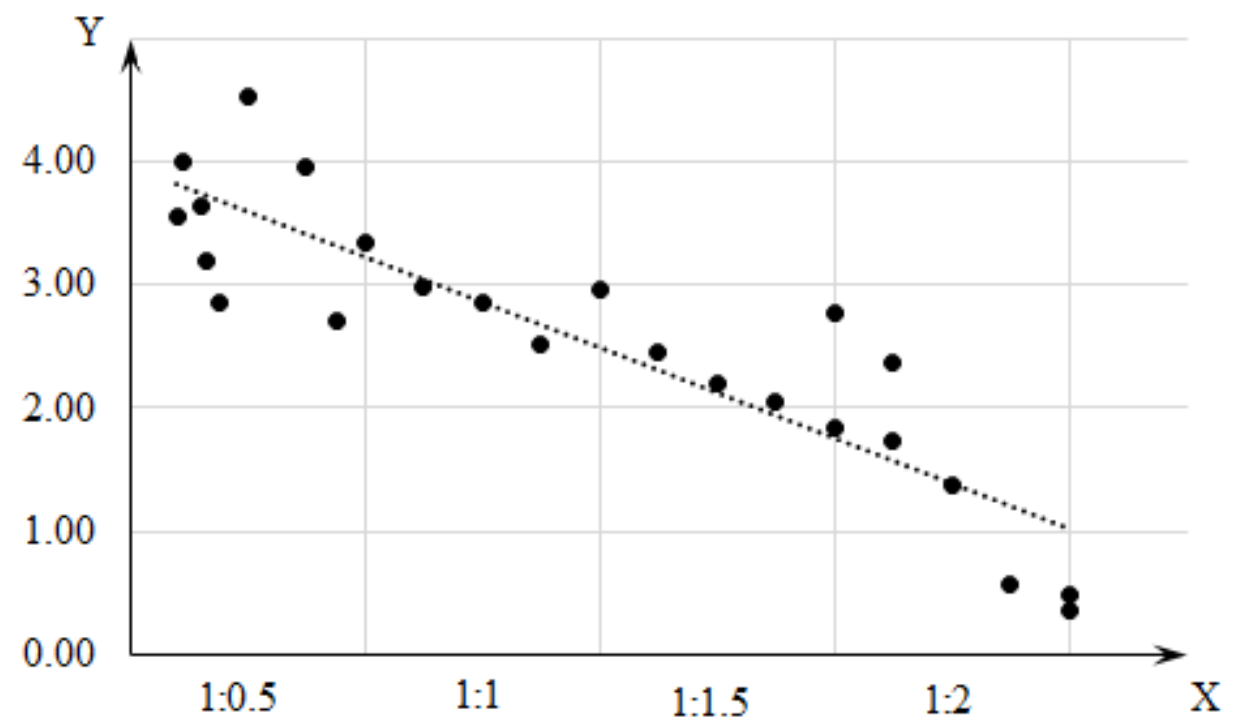

Fig 1. Scatter plot for Methylene blue: $\mathrm{X}$ is the dye:surfactant ratio, $\mathrm{Y}$ is the dye residual concentration

Table 3. Degree of correlation between process variables and anionic dyes residual concentration.

\begin{tabular}{|l|c|c|c|c|}
\hline \multirow{2}{*}{$\begin{array}{c}\text { Process } \\
\text { variables }\end{array}$} & \multicolumn{4}{|c|}{ Correlation coefficient of Anionic Dyes } \\
\cline { 2 - 5 } & $\begin{array}{c}\text { Acid Red } \\
1\end{array}$ & $\begin{array}{c}\text { Disodium Reactive } \\
\text { Blue 4 }\end{array}$ & $\begin{array}{c}\text { Bromophenol } \\
\text { blue }\end{array}$ & $\begin{array}{c}\text { Indigo } \\
\text { carmine }\end{array}$ \\
\hline $\mathrm{pH}$ & 0.835 & 0.883 & 0.825 & 0.696 \\
\hline Contact time & -0.877 & -0.583 & -0.590 & -0.771 \\
\hline Dye : surfactant ratio & -0.328 & -0.318 & -0.758 & 0.466 \\
\hline
\end{tabular}

Table 4. Degree of correlation between process variables and cationic dyes residual concentration.

\begin{tabular}{|l|c|c|c|c|c|}
\hline \multirow{2}{*}{ Process variables } & \multicolumn{5}{|c|}{ Correlation coefficient of Cationic Dyes } \\
\cline { 2 - 6 } & $\begin{array}{c}\text { Malachite } \\
\text { green }\end{array}$ & $\begin{array}{c}\text { Methyl } \\
\text { violet }\end{array}$ & $\begin{array}{c}\text { Crystal } \\
\text { violet }\end{array}$ & $\begin{array}{c}\text { Methylene } \\
\text { blue }\end{array}$ & $\begin{array}{c}\text { Bromocresol } \\
\text { green }\end{array}$ \\
\hline pH & 0.381 & 0.291 & 0.966 & 0.915 & 0.234 \\
\hline Contact time & -0.823 & -0.916 & -0.686 & -0.724 & -0.669 \\
\hline Dye : surfactant ratio & 0.467 & -0.325 & -0.774 & -0.889 & 0.712 \\
\hline
\end{tabular}

At the next stage of the simulation, the coefficients of the mathematical model (2) are calculated. The example of mathematical model for Bromophenol blue dye is presented below:

$5,18 \cdot y^{\prime}+y=-0,10 \cdot x_{1}-5.09 \cdot 10^{-2} \cdot x_{2}+0.37 \cdot x_{3}$,

in which $y$ is the dye residual concentration $\mathrm{mg} / \mathrm{dm}^{3} ; x_{1}$ is $\mathrm{pH}$ value, $x_{2}$ is the dye : surfactant ratio; $x_{3}$ is the process time, min.

Fisher ratio in this case is 9.01, multiple correlation coefficient is 0.94 and RMSD is 0.219 . Thus, matching between experimental data and predicted results is quite satisfactory. The graph of the dye residual concentration change over time is shown in Fig. 2. As can be seen, the equation (3) describes the process of changing the Bromophenol blue dye concentration over time with a sufficient degree of accuracy. The equation (3) can be used to predict changes in the Bromophenol blue dye concentration. 


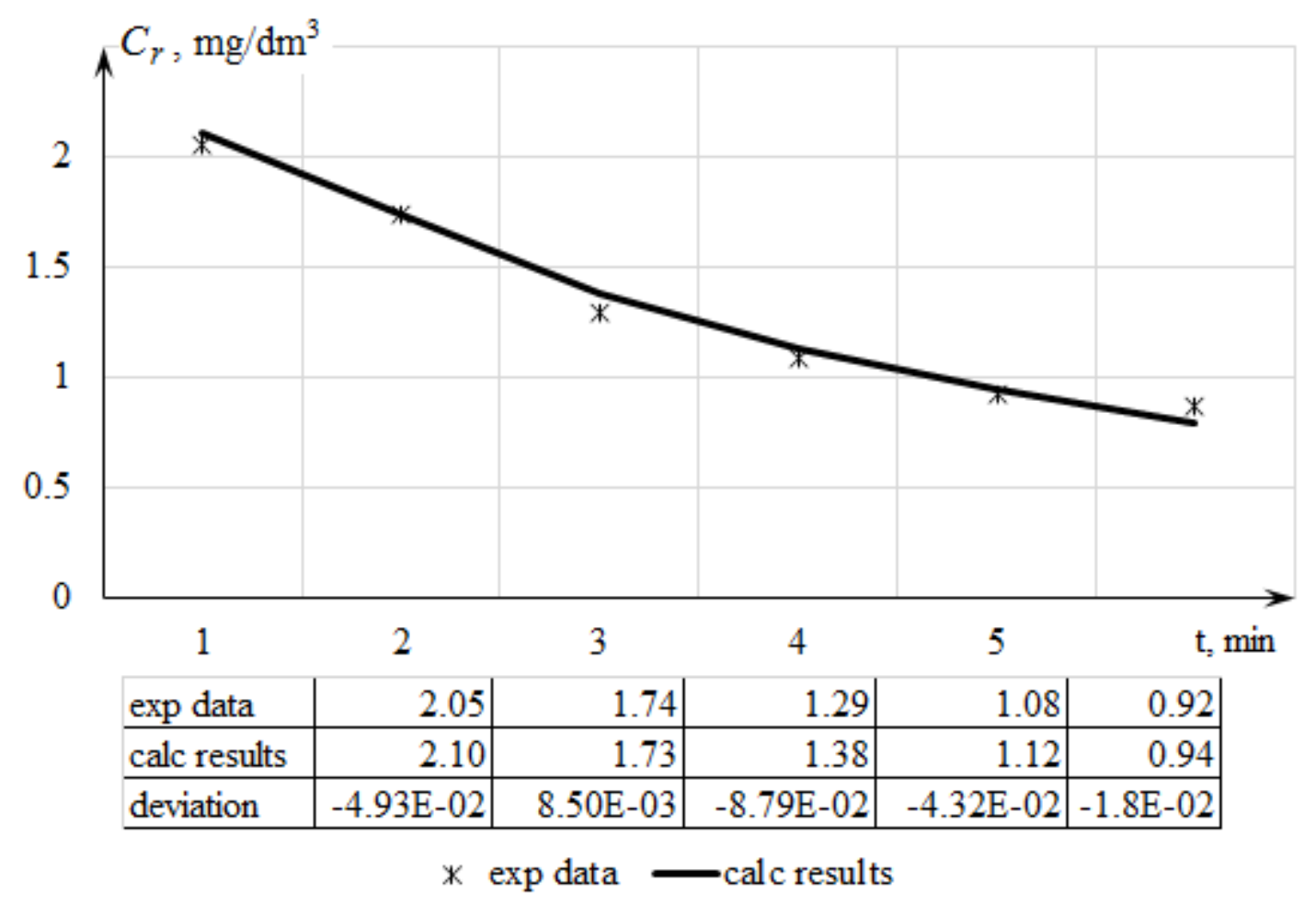

Fig 2. The Bromophenol blue dye residual concentration change over time

Table 5 shows the results of simulation of studied dyes residual concentration as well as statistical parameters of the obtained models. The output graphs of solvent sublation process simulation are shown in Fig. 3 and 4.

Table 5. Comparative table of studied dyes.

\begin{tabular}{|c|c|c|c|c|c|c|c|c|}
\hline \multirow{2}{*}{ \# } & \multirow{2}{*}{ Water-soluble dyes } & \multicolumn{4}{|c|}{ Coefficients of Equation (2) } & \multicolumn{3}{|c|}{ Statistical Parameters } \\
\hline & & $\mathrm{T}$ & $\mathrm{k}_{1}$ & $\mathrm{k}_{2}$ & $\mathrm{k}_{3}$ & $\mathrm{~F}$ & $\mathrm{r}$ & $\sigma$ \\
\hline \multicolumn{9}{|c|}{ Anionic Dyes } \\
\hline \multirow{2}{*}{1} & \multirow{2}{*}{ Acid Red 1} & 11.08 & $1.49 \cdot 10^{-2}$ & -0.07 & 0.30 & 2.42 & 0.77 & 0.42 \\
\hline & & 5.98 & 0.01 & -0.06 & 0.23 & 3.30 & 0.84 & 0.25 \\
\hline 2 & Disodium Reactive Blue 4 & 10.80 & -0.02 & -0.06 & 0.24 & 2.33 & 0.76 & 0.38 \\
\hline \multirow{2}{*}{3} & \multirow{2}{*}{ Bromophenol Blue } & 5.18 & -0.10 & -0.05 & 0.37 & 9.01 & 0.94 & 0.22 \\
\hline & & 9.96 & -0.06 & -0.04 & 0.22 & 4.02 & 0.87 & 0.27 \\
\hline \multicolumn{9}{|c|}{ Cationic Dyes } \\
\hline \multirow{2}{*}{1} & \multirow{2}{*}{ Malachite Green } & 5.88 & -0.03 & -0.12 & 0.60 & 2.64 & 0.79 & 0.50 \\
\hline & & 5.46 & 0.07 & -0.06 & 0.14 & 2.27 & 0.75 & 0.41 \\
\hline 2 & Methyl Violet & 19.95 & 0.01 & 0.00 & 0.01 & 1.97 & 0.70 & 0.15 \\
\hline \multirow{2}{*}{3} & \multirow{2}{*}{ Crystal Violet } & 5.52 & -0.15 & -0.10 & 0.68 & 7.87 & 0.93 & 0.40 \\
\hline & & 6.90 & -0.18 & -0.09 & 0.62 & 5.73 & 0.91 & 0.51 \\
\hline 4 & Bromocresol Green & 6.40 & 0.32 & -0.08 & 0.11 & 3.04 & 0.82 & 1.34 \\
\hline
\end{tabular}




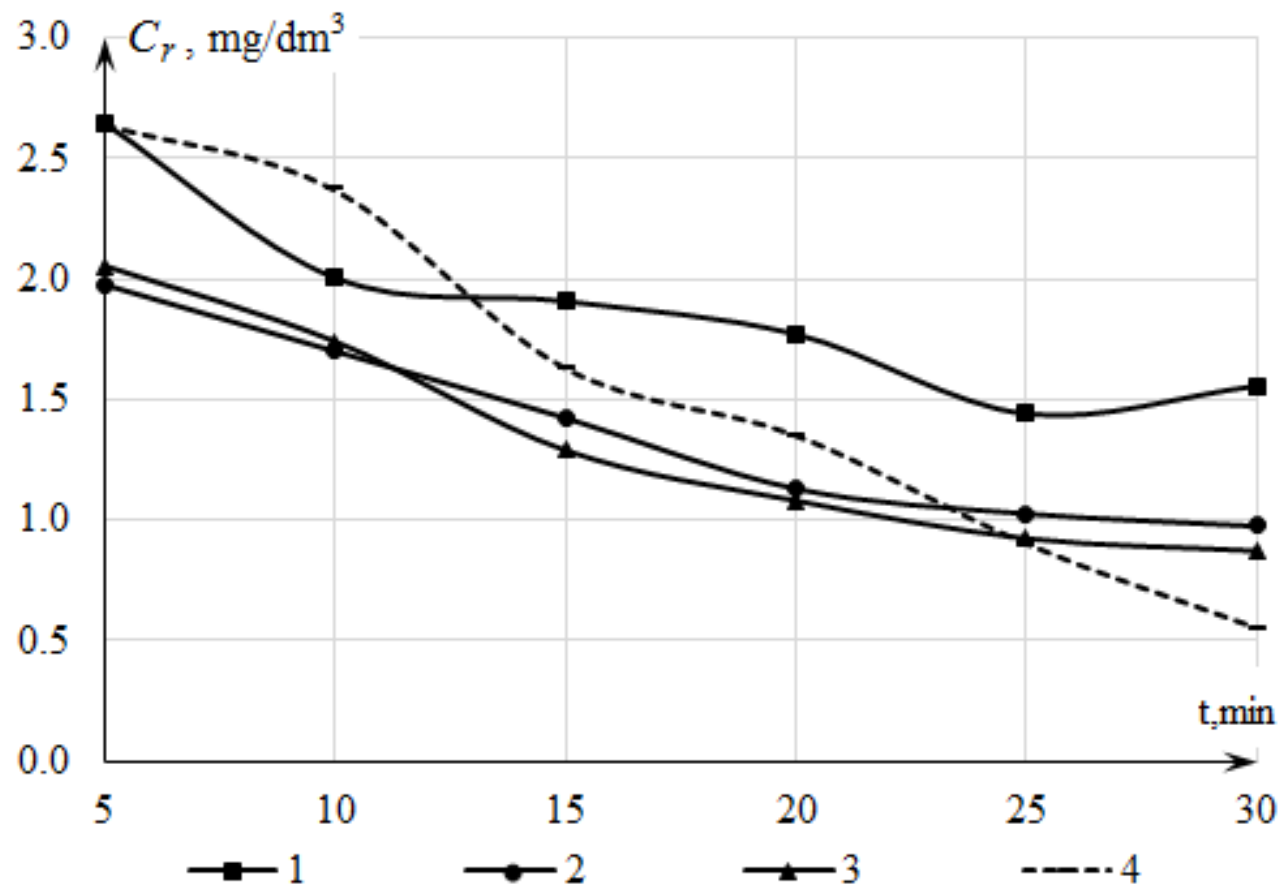

Fig. 3. Anionic dyes concentration change over time: 1 - Acid Red 1, 2 - Disodium Reactive Blue 4, 3 - Bromophenol Blue, 4 - Indigo Carmine.

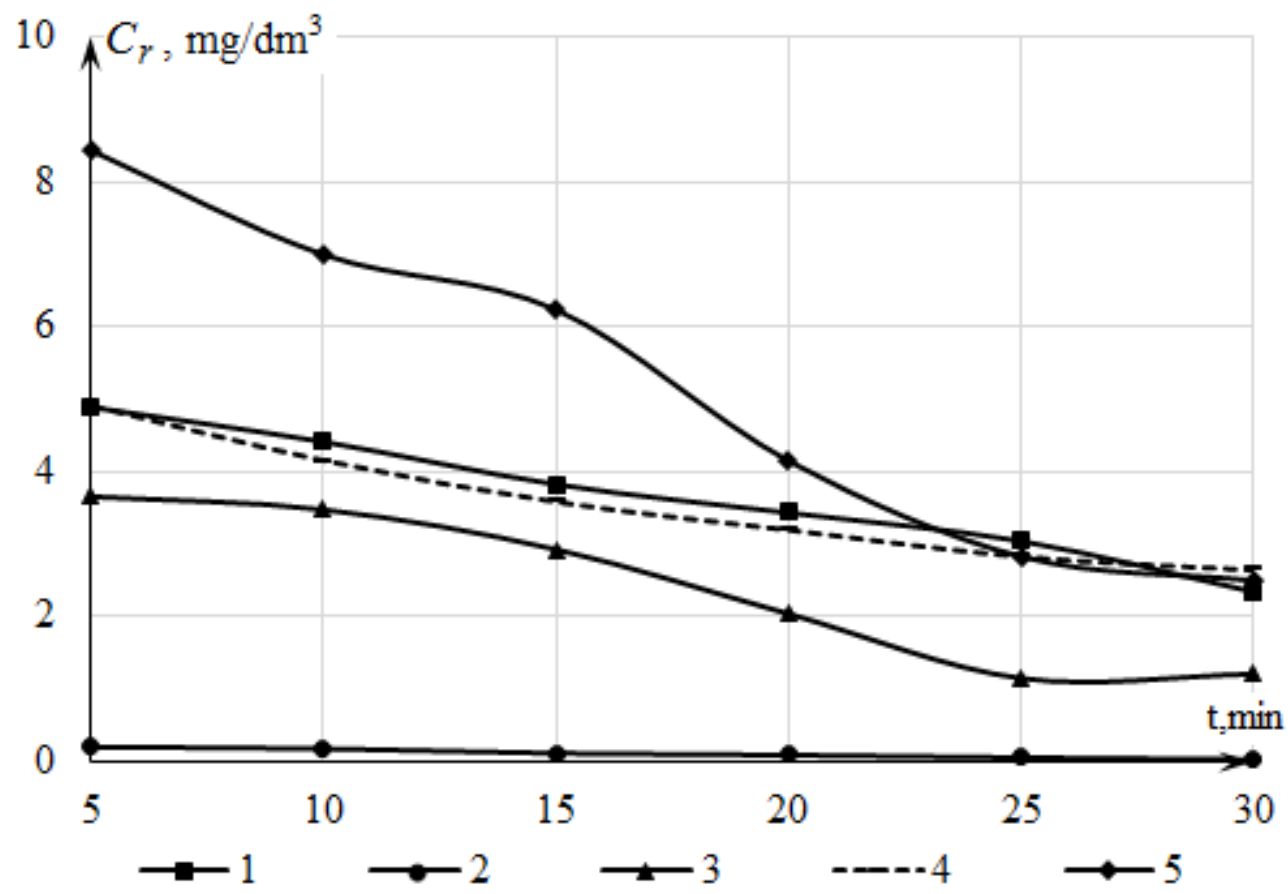

Fig. 4. Cationic dyes concentration change over time: 1 - Malachite Green, 2 - Methyl Violet, 3 Crystal Violet, 4 - Methylene Blue, 5 - Bromocresol Green.

It should be noticed that for the Indigo carmine and Methylene blue dyes are not possible to obtain a mathematical model with satisfactory statistical parameters. The residual concentration for these dyes is presented at Fig. 3 and 4 in the dotted line. In contrast, the models for dyes presented in the Table 5 can be used to predict the amount of dyes removal and to solve optimization tasks. 


\title{
Conclusion
}

In this paper, the correlation analysis has been used to determine the process variables that have a significant impact on the solvent sublation process and the STAR software has been applied to simulation of the different dye removal process. The ordinary first-order differential equation is used as a basic model describing the change in the dye concentration as a function of $\mathrm{pH}$ value, dye:surfactant ratio and the process time. The data set taken at various experimental conditions has been used to perform parametric identification. The performance of each model has been evaluated by statistical parameters and the studies have shown that the simulation model of Bromophenol Blue dye has a higher ability in prediction of dye removal in comparison with the other models. The obtained results can be used to improve the efficiency of the existing solvent sublation technique.

\section{МОДЕЛЮВАННЯ ПРОЦЕСУ ФЛОТОЕКСТРАКЦІЇ ДЛЯ ПРОГНОЗУВАННЯ ВИДАЛЕННЯ БАРВНИКІВ 3 ВОДНИХ РОЗЧИНІВ}

\author{
Т. Обушенко, О. Сангінова, Н. Толстопалова, К. Ремінна \\ Національний технічний університет України «Київський політехнічний інститут ім. Ігоря \\ Сікорського », Київ, Україна, e-mail: tio1963@gmail.com
}

Видалення водорозчинних барвників аніонного та катіонного типів з водних розчинів здійснювали методом флотоекстракиії. Метою досліджень є комп'ютерне моделювання процесу флотоекстракиіi як методу очищення стічних вод від барвників катіонного $i$ аніонного типів.

У даному дослідженні методи математичної статистики були використані для визначення факторів, які мають найбільший вплив на прочес флотоекстракиії. Встановлено, щзо такими чинниками є $p H$, співвідношення барвник : поверхнево-активна речовина і тривалість проиесу. Mатематичний апарат системи STAR використовувався для пошуку математичних моделей, які з достатнім ступенем адекватності описують зміну залишкової концентрації барвника в часі. У якості базової моделі запропоновано використовувати звичайне диференціальне рівняння першого порядку, яке описує зміну конщентрації барвника у часі. Параметричну ідентифікацію моделей для кожного барвника виконано засобами підсистеми GEM системи STAR. За результатами порівняльного аналізу статистичних характеристик математичних моделей визначено модель, яка найкращим чином описує процес видалення барвника з водного розчину.

Математичні моделі отримані для наступних барвників: легкозмиваємий червоний, активний яскраво-блакитний, бромфеноловий синій, малахітовий зелений, метиловий фіолетовий, кристалічний фіолетовий $і$ бромкрезоловий зелений. Адекватність отриманих моделей оцінювалася з використанням таких статистичних характеристик, як відношення Фішера, коефіцієнт множинної кореляиї̈ і середньоквадратичне відхилення. Результати моделювання показали, щзо отримані моделі мають прийнятні характеристики $i$ можуть бути використані для прогнозування ступеня видалення барвників катіонного і аніонного типів $з$ водних розчинів а також для оптимізаиії прочесу флотоекстракиії.

Ключові слова: барвник, математичне моделювання, стічні води, флотоекстракція.

\section{МОДЕЛИРОВАНИЕ ПРОЦЕССА ФЛОТОЭКСТРАКЦИИ ДЛЯ ПРОГНОЗИРОВАНИЯ УДАЛЕНИЯ КРАСИТЕЛЕЙ ИЗ ВОДНЫХ РАСТВОРОВ}

Вода і водоочисні технології. Науково-технічні вісті·№1(24) 2019 


\section{Т. Обушенко, О. Сангинова, Н. Толстопалова, К. Реминная}

Национальный технический университет Украины «Киевский политехнический институт им. Игоря Сикорского», Киев, Украина, e-mail: tio1963@gmail.com

Удаление водорастворимых красителей анионного и катионного типов из водных растворов осуществляли методом флотоэкстракции. Целью исследования является компьютерное моделирование процесса флотоэкстракционного удаления красителей катионного и анионного типов. В данном исследовании методы математической статистики использовались для определения факторов, оказывающих наибольшее влияние на процесс флотоэкстракиии. Математический аппарат системы STAR использовался для поиска математической модели, с достаточной степенью адекватности описывающую изменение остаточной концентрации красителя во времени. Результаты моделирования показывают, что полученные модели обладают удовлетворительныли характеристиками и могут быть использованы для прогнозирования степени удаления красителей катионного и анионного типов из водных раствора, а также для оптимизации процесса флотоэкстракции.

Ключевые слова: краситель, математическое моделирование, сточные воды, флотоэкстракиия.

\section{References}

Astrelin I. M., Obushenko T. I., Tolstopalova N. M., Targonska O. O. Theoretical principles and application of solvent sublation: a review. Voda i vodoochysni tehnologii'. 2013. 3, 3-23.

Bi P., Dong H., Dong J. S. D. Huang The recent progress of solvent sublation. Journal of Chromatography A. 2010. 1217(16), 2716-2725. doi: 10.1016/j.chroma.2009.11.020.

Bi P.Y. Solvent sublation of dyes Chin. Chem. Lett. 2007. 18, 1293.

Forgacs E., Cserha T., Oros G. Removal of synthetic dyes from wastewaters: a review. Environment International. 2004. 30(7), 953-971. doi: 10.1016/j.envint.2004.02.001.

Leskiv G.S. Ph.D (Techn.) Thesis. Lviv, 2008 [in Ukrainian].

Lu Y., Wang Y., Zhu X. The removal of bromophenol blue from water by solvent sublation. Separation Science and Technology. 2001. 36(16), 3763-3776. doi: 10.1081/ss-100108361.

Lu Y., Wei B., Wang Y., Li J. Studies on the removal of bromocresol green from water by solvent sublation // Separation Science and Technology. 2007. 42(8), 1901-1911. doi: 10.1080/01496390601174398.

Lu Y., Zhu X. Solvent sublation: theory and application. Separation \& Purification Reviews. 2001. 3(2), 157-189. doi: 10.1081/spm-100108158.

Lu Y., Zhu X., Peng Y. The removal of methyl violet from water by solvent sublation. Separation Science and Technology. 2003. 38(6), 1385-1398. doi: 10.1081/ss-120018815.

Nesterova L. A., Saribekov G. S., Efficiency of Use of Turnaround Systems of Water Consumption at the Textile Enterprises. Eastern-European Journal of Enterprise Technologies. 2010. 4(8(46)), 2528. doi:http://dx.doi.org/10.15587/1729-4061.2010.3022.

Ratnaweera H., Astrelin I. et al.,: Physico-chemical methods of water treatment. Water management. Kyiv: Water Harmony Process, 2015 [In Ukrainian].

Sanginova O., Kulevskiy E. Simulation of Municipal Wastewater Treatment Process. 6th International Scientific-Practical Conference Computer Modeling for Chemistry, Technologies and Sustainable Development Systems. 16-18 May, Kyiv 2018. - P.208-210. ISBN 978-617-696-740-8 [In Ukrainian]. 